\title{
Attention deficit hyperactivity disorder: Training outcomes for Grade R teachers in an urban and semi-rural context
}

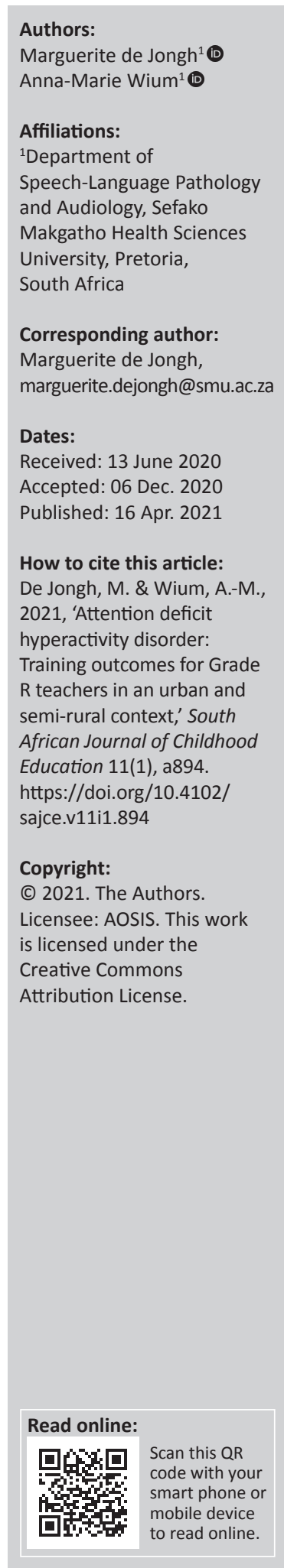

Background: Preschool learners with attention deficit hyperactivity disorder (ADHD) may develop problems with emergent literacy and more explicitly, phonological awareness necessary for the development of reading and writing. A need for support of Grade $\mathrm{R}$ teachers in inclusive schools was identified, and a programme developed.

Aim: The main aim of this article is to report on the outcomes of a support programme for Grade R teachers on ADHD in two contexts within a specific school district.

Setting: Participants were recruited from urban schools and township schools in a semi-rural context of a specific school district in Tshwane.

Methods: The outcomes of this support programme was determined from data obtained with self-constructed questionnaires, which consisted of mainly closed-ended questions, supported by a limited number of open-ended questions. The quantitative data was statistically analysed and described, whereas the qualitative data was described through inductive analyses. Participants consisted of 44 teachers from semi-rural and 21 from urban, inclusive schools who attended the training workshops.

Results: The results of the training indicated that urban teachers demonstrated better overall knowledge before the training. The post-training results indicated no statistically significant differences in knowledge after the training. Both groups benefitted from the programme. The rural participants showed more improvement as a result of the training.

Conclusion: The participants from semi-rural schools benefitted more from the training, emphasising underlying inequalities in the education levels of the two groups. This research provided a starting point and needs to be expanded to facilitate Grade R teachers' awareness and knowledge of ADHD.

Keywords: attention deficit hyperactivity disorder; ADHD support programme; emergent literacy; semi-rural; urban.

\section{Introduction}

Attention deficit hyperactivity disorder (ADHD), a neuro-developmental disorder is defined by the American Psychiatric Association (APA 2013) in the fifth edition of the Diagnostic and Statistical Manual of Mental Disorders (DSM-5) (De Jongh, Wium \& Basson 2019) as:

$[A]$ persistent pattern of inattention and/or hyperactivity [which] interferes with development, has symptoms presenting in two or more settings (e.g. at home, school, or work), and negatively impacts directly on social, academic or occupational functioning. (pp. 1)

As a result, learners with ADHD are more difficult to manage in a classroom setting than their typically developing peers. These learners appear not to listen, tend to be restless, disturb other learners in the classroom and are often not accepted by their peers (Procaccini 2013). Attention deficit hyperactivity disorder is, therefore, mainly characterised by inappropriate levels of inattention or hyperactive-impulsivity (Schellack \& Meyer 2012). It is a common psychiatric disorder identified and diagnosed in preschool children (De Jongh et al. 2019; Suvarna \& Kamath 2009). Learners with ADHD may present with phonological awareness (PA) problems, which is a component of emergent literacy and a prerequisite for the development of reading and writing (De Jongh 2017).

Prevalence figures on ADHD in South Africa (SA) are sparse, and even more so for Grade R learners. For school-aged learners, including Grade R learners, the prevalence has been reported to range 
between $5.4 \%$ and $8.7 \%$ (Chinawa et al. 2014). This is higher than for the general population, with a prevalence of $1.5 \%$.

The risk for preschool learners with ADHD who experience challenges with the development of PA is significant and may result in academic difficulties (De Jongh et al. 2019; Sims \& Lonigan 2013; Wessels 2011). Attention deficit hyperactivity disorder is considered a barrier to learning. It is, therefore, important that ADHD should be identified early to be suitably addressed. Many teachers are however not adequately informed to identify and manage the condition, or the implications thereof for the development of emergent literacy (De Jongh et al. 2019; Sims \& Lonigan 2013; Spangler \& Slate 2012). Additional support is therefore required to make teachers aware of such a diagnosis and for them to understand how this condition is identified. They should know what the symptoms or behaviour associated with ADHD are, as well as how such learners should be managed to limit the impact of ADHD on learning, particularly on emergent literacy. Emergent literacy encompasses components such as print concepts, alphabet knowledge, literate language and PA, which all impact on the development of reading and writing (Paul \& Norbury 2012).

Since 1994, inclusive education became reality in the new South African Constitution (Department of Education [DoE] 2001). This meant that the needs of all learners in the SA context, including learners with barriers to learning, would be accommodated and met (Amod, Vorster \& Lazarus 2013). Teachers have to manage large under-resourced classes (Lessing \& De Witt 2008), which is problematic, particularly when learners have barriers to learning and are difficult to manage in the classroom.

The Department of Basic Education (DBE) acknowledged that teachers required additional support in managing learners who experience barriers to learning to change the injustices of the past (Gumede 2017). Policy changes were set in place to help amend previous inequalities and to overcome the gaps in teachers' knowledge. These policies aspired to bring about a change from supporting the learner with learning difficulties to supporting the teacher (Wium \& Louw 2013). The successful implementation of these policies could, as a result impact positively on learner performance (Wium \& Louw 2015).

Implementing these policies has, however, not always been successful as seen in the results obtained in the PIRLS Literacy 2016 study (Howie et al. 2018) in which South African Grade 4 learners scored 320 which was below the lowest benchmark (400). The implication is that $78 \%$ of SA Grade 4 learners cannot read for comprehension.

The DBE is phasing in Grade R (reception year), which forms part of the Foundation Phase (De Jongh et al. 2019). Grade R teachers may find it particularly challenging to manage learners with ADHD, as this condition becomes more evident in the reception year (Wessels 2011). This situation warrants that Grade $\mathrm{R}$ teachers receive additional support. The retraining of teachers (Motshekga 2011) and teacher support is therefore, imperative.
Although, DoE has made provision for a support structure through district-based support teams (DBST) to assist teachers in inclusive schools, limited support is evident for learners with ADHD (Kern et al. 2015). A scarcity of research exists on the support provided to Grade $\mathrm{R}$ teachers in the identification and management of ADHD, or the impact this may have on emergent literacy. Only a few programmes have been developed with a focus on either ADHD or literacy development internationally and for the South African context. Several authors (Amod et al. 2013; Olivier, Anthonissen \& Southwood 2010; Perold, Louw \& Kleynhans 2010) emphasised the need for quality support programmes and guidelines for teachers in the identification (including referral procedures associated with ADHD) and management of the condition and related problems in the South African educational context. These studies specified that support programmes should address gaps in the teachers' overall knowledge on ADHD and its effect on emergent literacy. Programmes should improve Grade $\mathrm{R}$ teachers' knowledge, awareness, skills, motivation, values, accountability and attitudes regarding such barriers to learning. International studies, as presented by Syed and Hussein (2010) confirmed these recommendations, whereas Procaccini (2013) added that culture and environmental influences also need to be included in a support programme for ADHD. These previous studies focused more on the development of primary school teachers and were mostly conducted in developed countries and urban contexts.

Previous studies provided guidelines for the development of the support programme (De Jongh et al. 2019). The recommendations and guidelines presented by Jones and Chronis-Tuscano (2008), Syed and Hussein (2010), Procaccini (2013), Perold et al. (2010), Wium (2010) and Wessels (2011) reiterated that training is most effective when groups are smaller; the training is applied for shorter periods and serves a preventative purpose. However, none of these researchers provided support to teachers on the early identification of ADHD related behaviours (emergent literacy), and the management of ADHD. Most of the researchers also specified that the link between ADHD and emergent literacy and the impact thereof should be addressed, which are considered as the outcomes for this specific study.

This research incorporated recommendations from previous studies to develop a programme for Grade R teachers in both urban and semi-rural contexts, which included teachers from township areas (De Jongh 2017). Relevant guidance through workshops allows Grade R teachers to identify and manage learners with ADHD. Teachers will therefore, be enabled to support such learners both socially and academically (Murray 2009; Perold et al. 2010) and possibly, prevent future problems with literacy acquisition (Procaccini 2013).

The support programme was presented in two different contexts within a specific school district for comparison purposes. Grade R teachers from both urban and township schools in a semi-rural context were included. It was 
important to determine whether the participants benefitted from the support provided.

\section{Aim}

The main aim of this article is to report on the outcomes of this specific support programme for Grade $\mathrm{R}$ teachers on ADHD in two different contexts. This article is a follow-up on a previous article (De Jongh 2019), which described the process of development of the support programme. The objectives for the research were to determine awareness and knowledge relating to the identification, diagnosis, symptoms and behaviour associated with ADHD, as well as the management thereof.

\section{Research methods and design Study design}

The research was based on the Intervention Research Model (Thomas \& Rothman 1994), which is a mixed method design (Creswell 2014) integrating both quantitative and qualitative domains to address the aim and consists of six phases. An adapted version of this model is presented in Table 1 (De Jongh et al. 2019). In this particular article, the focus is on Phase 3 that consists of data analysis (Step 1 and Step 2) and dissemination of results (Step 4 ) in the context of the main aim.

This article focuses mostly on the quantitative data obtained with self-constructed questionnaires embedded within an overall mixed methods study to describe the outcomes. The outcomes in this study relate to gains made in general awareness and knowledge pertaining to the identification, diagnosis, symptoms and behaviour associated with ADHD, as well as the management thereof.

\section{Setting}

Participants were recruited from urban schools and township schools in a semi-rural context of a specific school district in Tshwane.

\section{Study population and sampling strategy}

Grade $\mathrm{R}$ teachers in two contexts in one district of Tshwane were identified for the research. The Gauteng Department of Education was contacted, and a specific district was purposively selected for the research, based on an identified need for support. The district office included all the schools in their region, and all the Grade $\mathrm{R}$ teachers were invited. All participants were female. Teachers from urban schools were adequately qualified and were mostly white. Participation was voluntary, which was a convenience sampling method (non-probability sampling technique).

The semi-rural schools were situated outside the periphery of the city in a township, thus in a previously disadvantaged context. This group only included black teachers. Considering the history of South Africa under Apartheid rule before 1994, these teachers did not receive training similar to their white counterparts. The majority of the participants from semi-rural schools had a National Qualifications Framework (NQF) level 5 (vocational certificate) qualifications, whereas all of the urban school participants achieved at least level 6 on the NQF with the majority having an NQF level 7. Thus, the qualifications ranged from national diplomas to advanced certificates and bachelor's degrees.

A total of 65 Grade R teachers (44 from the township in the semi-rural context, and 21 from urban schools) provided consent for the research and attended the training workshops. The group sizes were not equal, as the participants volunteered in both contexts. Most of the participants from semi-rural schools (80\%) were between the ages of 36 and 50 years, whereas $52 \%$ of participants from the urban schools were mostly younger (aged between 21 years and 30 years). Therefore, the semi-rural school participants were, on average, much older than their urban peers. Furthermore, English was not the home language of any of the participants. In the urban schools, the teachers spoke mainly Afrikaans,

TABLE 1: Research process: Phases of the research.

\begin{tabular}{|c|c|c|c|c|}
\hline Step & $\begin{array}{l}\text { Preparation phase: Planning } \\
\text { and approval }\end{array}$ & $\begin{array}{l}\text { Phase 1: Programme } \\
\text { development }\end{array}$ & $\begin{array}{l}\text { Phase 2: Programme } \\
\text { implementation and } \\
\text { data collection }\end{array}$ & $\begin{array}{l}\text { Phase 3: Data analysis and } \\
\text { dissemination of results }\end{array}$ \\
\hline Step 1 & $\begin{array}{l}\text { Permission from DBE, School } \\
\text { Research Ethics Committee (SREC) } \\
\text { and Medunsa Research Ethics } \\
\text { Committee (MREC) }\end{array}$ & $\begin{array}{l}\text { Review relevant literature on: } \\
\text { - ADHD } \\
\text { - Emergent literacy } \\
\text { - Adult learning } \\
\text { - Eco-systemic model }\end{array}$ & $\begin{array}{l}\text { - Brief district facilitator (DBE) } \\
\text { - Invite teachers to participate } \\
\text { in the support programme }\end{array}$ & $\begin{array}{l}\text { Quantitative data analysis } \\
\text { (close-ended questions) }\end{array}$ \\
\hline Step 2 & $\begin{array}{l}\text { Develop baseline questionnaire - } \\
\text { Questionnaire } 1\end{array}$ & $\begin{array}{l}\text { Develop the support programme } \\
\text { and training manual according to } \\
\text { the literature review indicated } \\
\text { in Step } 1\end{array}$ & Informed consent & $\begin{array}{l}\text { Qualitative data analysis } \\
\text { (open-ended questions) }\end{array}$ \\
\hline \multirow[t]{2}{*}{ Step 3} & - Brief district facilitator (DBE) & - Finalise questionnaires & $\begin{array}{l}\text { Baseline or pre-training } \\
\text { data collection }\end{array}$ & $\begin{array}{l}\text { Qualitative data analysis } \\
\text { (focus groups) }\end{array}$ \\
\hline & $\begin{array}{l}\text { - Invite teachers to participate } \\
\text { in the support programme }\end{array}$ & - Finalise focus group questions & - & - \\
\hline Step 4 & - & - & Programme implementation & $\begin{array}{l}\text { - Dissemination of results } \\
\text { - Report to the DBE }\end{array}$ \\
\hline Step 5 & - & - & $\begin{array}{l}\text { Post-training data collection } \\
\text { (Questionnaire 2) }\end{array}$ & - \\
\hline Step 6 & - & - & Focus group discussions & - \\
\hline
\end{tabular}


and in the township schools the home languages were either Sepedi $(45.5 \%)$ or Setswana $(34.8 \%)$.

\section{Programme implementation}

For clarity purposes, a summary of the original programme that was developed and implemented by a speech-language therapist is presented in Table 2 (De Jongh 2017; De Jongh et al. 2019) and is not discussed in this article. The support programme developed and presented in the original research was based on a combination of Bronfenbrenner's eco-systemic theory, intervention research model and adult learning principles (De Jongh 2017) as these models are inherent to teacher support. The training was presented in English, but an assistant researcher code-switched whenever participants requested clarification.

\section{Data collection}

Quantitative and qualitative data were collected for 65 participants using two self-constructed questionnaires, which were adapted from the original KADDS (Knowledge of Attention Deficit Disorders Scale) by Sciutto, Terjesen and Bender (2000). The KADDS is one of the most widely used instruments to assess teachers' knowledge of ADHD (Perold et al. 2010). Additionally, literature on ADHD was used to construct the two questionnaires. These questionnaires (De Jongh 2017) consisted mostly of closed-ended questions, supported by a limited number of open-ended questions. These questionnaires included different sections:

- Section 1 of the pre-training questionnaire elicited demographic information of the participants.

- Section 2 of pre- and post-training questionnaires contained questions on general aspects of ADHD, namely, diagnosis, identification, symptoms and behaviour, as well as questions related to the management of ADHD.

- Section 3 of both questionnaires included questions related to emergent literacy that is, the impact of ADHD on emergent literacy, emergent literacy terminology and characteristics and the support provided for the development of emergent literacy.

- Section 4 of both questionnaires consisted of questions relating to the need for additional support, as indicated by the participants.

- Section 5 in the post-training questionnaire, participants were given an opportunity to provide feedback on the benefits of the training and whether their expectations had been met. It also required participants to provide additional comments on the training and to rate the training on a 5-point Likert scale.

The pre-training questionnaires were administered directly before the training workshop commenced. These provided base-line data relating to the teachers' demographic information, general knowledge of ADHD and emergent literacy, as well as their knowledge concerning the management thereof. An adapted version of the pre-training questionnaire was administered directly after the training to the 65 participants. The post-training questionnaire excluded the demographic information and added some open-ended questions to obtain the participants' views and experiences of the training, as well as remaining needs for follow-up training.

\section{Data analysis}

Both quantitative and qualitative results obtained from the pre-and post-training questionnaires were analysed to determine if the participants' awareness and knowledge improved as a result of the support programme.

\section{Quantitative data analysis}

Raw data as obtained from closed-ended questions was captured on Excel spreadsheet. Inferential statistics, utilising the McNemar test, was applied. This test reflected the 'actual' improvement in knowledge resulting from the support programme for each group. The Fisher exact test was also used to determine a statistically significant difference in knowledge for each of the areas assessed after the training, indicating how each of the two groups benefitted from the training. This was not done to compare knowledge, but rather determine the outcomes of the training.

The qualitative data, including participants' experiences and opinions on the training, obtained from the open-ended questions in the questionnaires, were then listed and entered into Excel spreadsheet where it was grouped and provided binary values. Descriptive statistics (percentages) were utilised, and the results were presented in tables to portray and compare the qualitative responses for each objective across the two contexts.

\section{Ethical considerations}

Ethical clearance was obtained from the Sefako Makgatho Health Sciences University Research and Ethics Committee, and permission for the research was granted by the Gauteng Department of Education (GDE). These measures ensured that the research met with all ethical requirements, for example, protection from harm, voluntary and informed participation and the right to privacy. Number: MREC/ M/336/2014:PG.

\section{Results and discussion}

Considering that this article reports on the outcomes of the training, specifically how each of the two groups benefitted from the training, the two groups were compared in terms of their increase in knowledge. Such findings were obtained by comparing the pre- and post-training knowledge of ADHD in terms of identification, diagnosis, symptoms, behaviour associated with ADHD and the management thereof for each 
TABLE 2: Outline of the support programme: Aims, outcomes, assessment criteria, activities, teaching and learning strategies and assessment strategies.

\begin{tabular}{|c|c|c|c|c|}
\hline $\begin{array}{l}\text { Sub-aims (What the } \\
\text { researcher intends to } \\
\text { accomplish with the } \\
\text { training) - Aim } 1\end{array}$ & $\begin{array}{l}\text { Specific outcomes (SOs) (What the Grade R } \\
\text { teachers are expected to know, understand and } \\
\text { implement after the training) }\end{array}$ & $\begin{array}{l}\text { Assessment criteria (AC) (Manner in which to } \\
\text { determine if the SO was met) }\end{array}$ & $\begin{array}{l}\text { Activities (How } \\
\text { the aims and } \\
\text { activities will } \\
\text { be met) }\end{array}$ & $\begin{array}{l}\text { Teaching and } \\
\text { learning } \\
\text { strategies (How?) }\end{array}$ \\
\hline
\end{tabular}

\begin{tabular}{|c|c|c|c|c|c|c|c|c|}
\hline & & & & & & & \\
\hline & SO1 & SO2 & SO3 & AC1 & AC2 & $\mathrm{AC3}$ & & \\
\hline $\begin{array}{l}\text { To improve the } \\
\text { participants' general } \\
\text { knowledge and } \\
\text { understanding of the } \\
\text { following topics: }\end{array}$ & $\begin{array}{l}\text { - Identify the } \\
\text { factors that } \\
\text { contribute } \\
\text { to and are } \\
\text { associated } \\
\text { with ADHD }\end{array}$ & $\begin{array}{l}\text { - Identify the } \\
\text { different } \\
\text { steps in the } \\
\text { assessment } \\
\text { and } \\
\text { identification } \\
\text { process }\end{array}$ & $\begin{array}{l}\text { - Select and } \\
\text { recommend } \\
\text { appropriate } \\
\text { learning material } \\
\text { for emergent } \\
\text { literacy } \\
\text { (phonological } \\
\text { awareness }\end{array}$ & $\begin{array}{l}\text { Grade } R \text { teachers } \\
\text { demonstrate } \\
\text { improved } \\
\text { understanding by } \\
\text { reflecting on } \\
\text { their: }\end{array}$ & $\begin{array}{l}\text { Grade } R \text { teachers } \\
\text { demonstrate } \\
\text { improved } \\
\text { understanding by } \\
\text { reflecting on: }\end{array}$ & $\begin{array}{l}\text { Grade } R \text { teachers } \\
\text { display improved } \\
\text { understanding by } \\
\text { reflecting on: }\end{array}$ & $\begin{array}{l}\text { A 20-min group } \\
\text { discussion before } \\
\text { presentation }\end{array}$ & $\begin{array}{l}\text { - Thematic } \\
\text { learning }\end{array}$ \\
\hline $\begin{array}{l}\text { - Ability to select and } \\
\text { apply appropriate } \\
\text { identification } \\
\text { or assessment } \\
\text { procedures }\end{array}$ & $\begin{array}{l}\text { - Identify the } \\
\text { relationship } \\
\text { between } \\
\text { ADHD and } \\
\text { co- } \\
\text { morbidities } \\
\text { (emergent } \\
\text { literacy) }\end{array}$ & - & $\begin{array}{l}\text { - Identify, select } \\
\text { and recommend } \\
\text { team members in } \\
\text { the management } \\
\text { of learners with } \\
\text { ADHD and } \\
\text { associated } \\
\text { emergent literacy } \\
\text { problems }\end{array}$ & $\begin{array}{l}\text { - Characteristics } \\
\text { symptoms } \\
\text { in learners } \\
\text { associated } \\
\text { with ADHD }\end{array}$ & $\begin{array}{l}\text { Demonstrate } \\
\text { how the DSM-5, } \\
\text { checklists and } \\
\text { rating scales can } \\
\text { be utilised in } \\
\text { the identification } \\
\text { of learners with } \\
\text { ADHD }\end{array}$ & $\begin{array}{l}\text { - The management } \\
\text { of ADHD and } \\
\text { emergent } \\
\text { literacy } \\
\text { (post-training) }\end{array}$ & $\begin{array}{l}\text { Powerpoint } \\
\text { presentation and } \\
\text { group discussion } \\
\text { on the relation } \\
\text { between ADHD } \\
\text { and emergent } \\
\text { literacy }\end{array}$ & $\begin{array}{l}\text { - Direct } \\
\text { instruction }\end{array}$ \\
\hline $\begin{array}{l}\text { - Management of } \\
\text { ADHD and } \\
\text { emergent literacy } \\
\text { (Phonological } \\
\text { awareness) }\end{array}$ & - & - & $\begin{array}{l}\text { Demonstrate how } \\
\text { the learning } \\
\text { environment } \\
\text { can be adapted }\end{array}$ & $\begin{array}{l}\text { - The relationship - } \\
\text { between ADHD } \\
\text { and emergent } \\
\text { literacy } \\
\text { development }\end{array}$ & & $\begin{array}{l}\text { - The role of } \\
\text { different team } \\
\text { members in the } \\
\text { management of } \\
\text { ADHD and } \\
\text { emergent literacy } \\
\text { problems }\end{array}$ & $\begin{array}{l}\text { - Presentation on } \\
\text { identification } \\
\text { procedures }\end{array}$ & - Hands-on tasks \\
\hline $\begin{array}{l}\text { - Carry over into the } \\
\text { classroom context } \\
\text { and other 'systems' } \\
\text { that is, home } \\
\text { environment }\end{array}$ & - & - & - & - & 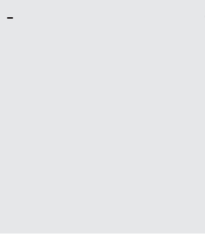 & $\begin{array}{l}\text { - Learning } \\
\text { environment } \\
\text { adaptations in } \\
\text { the management } \\
\text { of learners with } \\
\text { ADHD and } \\
\text { associated } \\
\text { emergent literacy } \\
\text { problems }\end{array}$ & $\begin{array}{l}\text { - Application and } \\
\text { group discussion } \\
\text { on the use of } \\
\text { rating scales, } \\
\text { checklists and } \\
\text { DSM-5 }\end{array}$ & - Feedback \\
\hline
\end{tabular}

- Presentation of - Applied learning identified programme for the management of emergent literacy: $20 \mathrm{~min}$

\begin{tabular}{|c|c|c|c|c|c|c|c|c|c|}
\hline & & & & & & & & & \\
\hline - & - & - & - & - & - & - & - & $\begin{array}{l}\text { Presentation } \\
\text { and group } \\
\text { discussion on } \\
\text { inter-relationship } \\
\text { between DoE } \\
\text { and support } \\
\text { programme } \\
\text { outcomes }\end{array}$ & $\begin{array}{l}\text { - Direct } \\
\text { presentation }\end{array}$ \\
\hline - & - & - & - & - & - & - & - & $\begin{array}{l}\text { Presentation and } \bullet \\
\text { group discussion } \\
\text { on the role of } \\
\text { different team } \\
\text { members }\end{array}$ & - Hands-on tasks \\
\hline - & - & - & - & - & - & - & & $\begin{array}{l}\text { Presentation and } \\
\text { group discussion } \\
\text { on learning } \\
\text { environment } \\
\text { adaptations: link } \\
\text { with case study }\end{array}$ & - Feedback \\
\hline - & - & - & - & - & - & - & - & - & $\begin{array}{l}\text { - Self-directed } \\
\text { learning }\end{array}$ \\
\hline
\end{tabular}

Source: De Jongh, M., 2017, 'The development of a support programme for grade R teachers to facilitate knowledge of attention deficit hyperactivity disorder and emergent literacy in a District of Tshwane', Doctoral dissertation, Sefako Makgatho Health Sciences University, Ga-Rankuwa, Pretoria; De Jongh, M., Wium, A.-M. \& Basson, W., 2019, 'The piloting of a specific support programme for Grade R teachers on attention deficit hyperactivity disorder: The process of development', South African Journal of Communication Disorders 66(1), a600. https://doi.org/10.4102/sajcd.v66i1.600 ADHD, attention deficit hyperactivity disorder; DSM-5, Diagnostic and Statistical Manual of Mental Disorders. 
group. The outcomes were determined by comparing the status of their knowledge gains between the two groups and not between individuals.

\section{Quantitative and qualitative results: Pre-training}

This section of the discussion provides a summary of the results obtained from the pre-training questionnaires. From the start of the research, there has been a difference between the two contexts. Urban school participants demonstrated overall better knowledge of ADHD and its effect on emergent literacy. They also showed more diversity in the level of support provided to learners with ADHD, as most urban school participants indicated that they had hands-on experience in managing the condition.

These differences in pre-training knowledge might be explained by the demographic information of the two groups. The majority of the participants $(84 \%)$ from semi-rural schools had an NQF level 5 (vocational certificate) qualifications, which differed significantly $(p<0.001)$ from the urban school participants. The majority $(76 \%)$ of the urban school participants' qualifications were of NQF level 7. This highlighted the inequalities in the education of previously disadvantaged teachers in the South African education context, which may have resulted in teachers' inadequate knowledge of specific topics (Spaull 2013). In addition, the participants from urban schools were, on average, much younger than their counterparts from the semi-rural context, which implies that they have received more recent and relevant training. These discrepancies in qualifications might indicate that urban school participants had existing pretraining knowledge on how to identify and manage learners with ADHD, which the semi-rural participants lacked.

\section{Quantitative and qualitative results: Post-training}

The following areas were assessed in the questionnaires, namely, general awareness of ADHD, which included the symptoms, behaviour, identification and diagnosis.

The quantitative results (descriptive statistics) indicated that the outcome of the training mostly confirmed improved knowledge for both groups. Apart from knowledge with regards to the measures, such as rating scales, used to identify ADHD, the semi-rural participants' general knowledge improved more than their urban counterparts as a result of the training. These results confirm those by Syed and Hussein (2010) and Kern et al. (2015), who found that teachers' awareness and knowledge of ADHD improved after participation in specific ADHD training.

The McNemar test results correlate with the findings of the descriptive statistics. Adedokun and Burgess (2011:125) state that the McNemar test is the most appropriate tool for [statistically] analysing pre- and post-differences in dichotomous items (e.g. "yes" or "no")'. The McNemar test was used to make statistical decisions, namely, comparing and analysing the pre- and post-training data to determine whether the support programme had a significantly positive effect on the teachers' awareness and knowledge concerning ADHD and its effect on emergent literacy. Such results indicated statistically significant differences between pre- and post-training responses. A statistical significance for the McNemar test is attained when the $p$-value is at a 0.05 level of significance or less $(p<0.05)$.

A summary of the $p$-values, concerning both groups' awareness and general knowledge of ADHD, is reflected in Table 3. Some of the McNemar Test results ( $p$-values) are not displayed because of missing values or no answers provided to some questions. Missing values indicate a non-response or a provision of more than one response. Completion of questionnaires was voluntary, and participants were not pressured to complete all questions, which account for the number of non-response. The data omitted for dichotomous items in the questionnaires could have impacted on the validity of the results as presented in Tables 3 and 4 . Education research is conducted in real-life contexts, which in itself is complex (Mohangi et al. 2016).

The results showed an improved awareness and general knowledge of ADHD for each of the two groups. Statistical significance for improvement in most of the areas assessed was obtained for the semi-rural group. Urban school participants' knowledge improved significantly for aspects related to 'symptoms', 'activity levels' and 'maturity levels' demonstrated by learners with ADHD. However, the gains made by the urban group was less than that made by the semi-rural group, which may be because of prior knowledge of some of the aspects assessed, such as for the professional team members.

TABLE 3: Outcomes of participants' awareness and general knowledge of attention deficit hyperactivity disorder.

\begin{tabular}{|c|c|c|}
\hline Aspects assessed & $\begin{array}{l}\text { p-values: } \\
\text { Semi-rural schools }\end{array}$ & $\begin{array}{l}p \text {-values: } \\
\text { Urban schools }\end{array}$ \\
\hline $\begin{array}{l}\text { Diagnosis of ADHD: Most } \\
\text { commonly diagnosed } \\
\text { psychiatric disorder }\end{array}$ & $0.0196 *$ & Not applicable \\
\hline ADHD diagnosis & $0.0075^{*}$ & Not significant (0.1573) \\
\hline Referral process & $0.4555^{*}$ & Not applicable \\
\hline ADHD symptoms & $0.0002 *$ & $0.0016 *$ \\
\hline $\begin{array}{l}\text { Activity levels associated } \\
\text { with ADHD }\end{array}$ & $0.0009 *$ & $0.0009 *$ \\
\hline $\begin{array}{l}\text { Behaviour of learners } \\
\text { with ADHD }\end{array}$ & $0.0339 *$ & Not significant (0.0578) \\
\hline $\begin{array}{l}\text { Maturity levels of learners } \\
\text { with ADHD }\end{array}$ & $0.0348 *$ & $0.0047 *$ \\
\hline $\begin{array}{l}\text { Emotional well-being } \\
\text { of learners with ADHD } \\
\text { (learners have mood } \\
\text { swings) }\end{array}$ & $\begin{array}{l}\text { Not significant } \\
(0.0588)\end{array}$ & Not applicable \\
\hline $\begin{array}{l}\text { Emotional well-being of } \\
\text { learners with ADHD } \\
\text { (learners are easily } \\
\text { frustrated) }\end{array}$ & $0.0143 *$ & Not applicable \\
\hline
\end{tabular}

Source: De Jongh, M., Wium, A.-M. \& Basson, W., 2019, 'The piloting of a specific support programme for Grade R teachers on attention deficit hyperactivity disorder: The process of development', South African Journal of Communication Disorders 66(1), a600. https://doi. org/10.4102/sajcd.v66i1.600

Note: Not applicable refers to results not determined because of missing values for certain dichotomous items.

ADHD, attention deficit hyperactivity disorder.

*, Statistically significant improvement as a result of the training. 
Improved awareness and knowledge on the general aspects related to ADHD may assist teachers in identifying the impact of ADHD on a learner's classroom behaviour and scholastic achievement (Guerra \& Brown 2012), and may also affect the referral process, diagnosis and educational management of learners with this disorder (Lessing \& Wulfsohn 2015). The role of teachers in the identification and referral of learners for an ADHD diagnosis is crucial. Alkahtani (2013:963) is of the opinion that 'teachers are valuable sources of information with regard to diagnosis of ADHD because of their daily contact with children'.

After the training, the semi-rural participants' general knowledge concerning the diagnosis of ADHD, as reflected in the qualitative results, reflected a high percentage of inappropriate responses, whereas the urban school participants' understanding visibly improved. The answers presented, provided evidence that semi-rural teachers may have confused the terms 'identification' and 'diagnosis' in relation to ADHD, which was also found by Perold et al. (2010). Such findings could be attributed to the lack of English language proficiency of semi-rural teachers. The home languages of most of the township school participants were indicated as either being Sepedi (45.5\%) or Setswana (34.8\%). Because of a segregated past under Apartheid, it can be assumed that the majority of semi-rural teachers came from educationally disadvantaged backgrounds (De Jongh 2017).

Participants' awareness and knowledge concerning the management options as well as specific support available for learners with ADHD were also explored. Domineering and bossy behaviour presented by some learners with ADHD may be challenging to manage (Lopes 2008) and might even be viewed as 'behavioural problems' (Amod et al. 2013). Teachers therefore, require training on how to improve and support these learners within the educational environment (Lessing \& Wulfsohn 2015).

The quantitative results indicate improved knowledge for both groups concerning external support provided for learners with ADHD. External or additional support refers to intervention by speech-language therapists and other professionals (e.g. psychologists, occupational therapists). This also includes the impact of pharmacotherapy on their behaviour, considering that Schellack and Meyer (2012) explained how pharmacotherapy could support learners to pay attention in class. A summary of the McNemar test results is presented in Table 4 .

The results, as portrayed in Table 4, show that participants from semi-rural schools' knowledge improved significantly for aspects assessed, particularly with regards to external support that is available for such learners $(p<0.0001)$. The participants also developed insight in terms of the role of pharmacotherapy $(p<0.0001)$ on the behaviour of learners with ADHD. The urban school participants' knowledge also improved, although not significantly as they had some prior knowledge of the impact of pharmacotherapy on the behaviour of learners with ADHD.
TABLE 4: Outcomes of participants' knowledge on the management and support of attention deficit hyperactivity disorder.

\begin{tabular}{lll}
\hline Aspects assessed & $\begin{array}{l}p \text {-values: } \\
\text { Semi-rural schools }\end{array}$ & $\begin{array}{l}p \text {-values: } \\
\text { Urban schools }\end{array}$ \\
\hline $\begin{array}{l}\text { External support for learners } \\
\text { with ADHD }\end{array}$ & $0.0001^{*}$ & Not applicable \\
Impact of pharmacotherapy & $0.0001^{*}$ & Not significant (0.0833)
\end{tabular}

Source: De Jongh, M., Wium, A.-M. \& Basson, W., 2019, 'The piloting of a specific support programme for Grade R teachers on attention deficit hyperactivity disorder: The process of development', South African Journal of Communication Disorders 66(1), a600. https://doi. org/10.4102/sajcd.v66i1.600

Note: Not applicable refers to results not determined because of missing values for certain dichotomous items.

$A D H D$, attention deficit hyperactivity disorder.

*, Statistical significant improvement as a result of the training.

The qualitative results showed improved knowledge of both groups with regard to the type of support provided, suggestions for external support and the effectiveness of support provided to learners with ADHD. Perold et al. (2010) similarly indicated that teachers are mostly aware of the benefits of pharmacotherapy to support learners to pay attention in a classroom setting (Schellack \& Meyer 2012). The urban participants in this study demonstrated improved knowledge on the possible side-effects related to pharmacotherapy. In contrast with this, Kern et al. (2015) reported that some Foundation Phase teachers displayed negative attitudes towards the use of medication because of the adverse side effects.

In this study, both groups acknowledged that diverse management options should be offered to learners with ADHD. Stimulant medication on its own was not effective as a treatment option (Kern et al. 2015) and should form part of a multimodal treatment approach (Schellack \& Meyer 2012). Kern et al. (2015) suggested several management options for learners with ADHD, namely medical intervention (use of psycho-stimulant medication), behavioural management and academic support. These approaches could assist learners' cognitive, social and emotional functioning as well as support learners to realise their academic potential (Flisher \& Hawkridge 2013).

The results pertaining to the management of ADHD mostly indicated improved knowledge for the semi-rural school participants for both the quantitative and the qualitative domains except for the side effects associated with pharmacotherapy. The urban school participants also improved in all the domains assessed, even though the improvement was not always significant because of more prior knowledge concerning the external support available for learners with ADHD and the impact of pharmacotherapy on learners' behaviour. Urban teachers are mostly in an ideal position to refer learners for external support as they have easier access to professionals (Kern et al. 2015) than their semi-rural peers (Wium \& Louw 2013).

Another positive result of the training was that both groups of participants highlighted that parents should be trained and become involved in the support provided to learners with ADHD. The same sentiment was echoed by Perold et al. (2010) and Schellack and Meyer (2012). A supportive 
relationship and close contact between parents and teachers may support the development and behaviour of learners with ADHD (Bronfenbrenner 2005).

The results obtained confirmed the notion that direct training will affect not only the referral process and diagnosis but also the management of the condition (Lessing \& Wulfsohn 2015).

As ADHD impacts negatively on the development of emergent literacy skills and consequently on the scholastic development of learners (Lopes 2008), participants' general knowledge and knowledge on the management of emergent literacy were likewise assessed.

A summary of the quantitative results pertaining to the management of emergent literacy indicates that participants' from both groups improved their knowledge relating to the characteristics of emergent literacy and the support provided to learners who experience problems with the development thereof. The characteristics, including appreciating and enjoying books, noticing print, recognising letters and identifying sounds and syllables, were specified by the participants as being core features of emergent literacy. These core characteristics support the attainment of literacy during formal schooling (Owens, Metz \& Farinella 2010; Paul \& Norbury 2012).

The McNemar test results show that participants' knowledge of the aspects related to the general knowledge and management of emergent literacy improved. Once again, the semi-rural teachers gained significantly more knowledge in this aspect $(p<0.0253)$. No significant improvement was observed of the participants from urban schools because of their prior knowledge in this regard. This outcome might again be related to urban school participants' qualifications or level of training.

Overall, the participants' responses reflected the pertinent literature on emergent literacy, namely that ADHD negatively influences learners' understanding of language. Literature likewise echoed that learners with barriers to learning, including ADHD, will have difficulty to reach their potential (Flisher \& Hawkridge 2013) and display a slower workpace (DSM-V 2013). The ability to process auditory information will also be affected (Sims \& Lonigan 2013). These negative consequences of ADHD will, therefore, adversely affect learners' scholastic achievement (Lopes 2008).

The qualitative findings confirmed the quantitative results. Both groups displayed improved awareness and knowledge relating to the impact that ADHD has on emergent literacy, the characteristics of emergent literacy aswell as the need for teacher support in assisting learners with emergent literacy problems. The urban school participants moreover improved their knowledge regarding the additional support (e.g. speech-language therapy) that should be provided for learners with emergent literacy problems. These results support the findings of Schellack and Meyer (2012). Both groups highlighted the role of parents, as originally explained by Bronfenbrenner's eco-systemic model (Bronfenbrenner 1979, 2005). Modisaotsile (2012) likewise emphasised that teachers and parents were mutually responsible for providing input to improve the academic outcomes of learners with ADHD.

The post-training responses that emerged from the open-ended questions correlate with the findings of Lopes (2008), who indicated that ADHD negatively influences reading competency. Poor reading is the result of pre-reading difficulties, which in turn is the cause of writing problems in school-aged learners (Wessels 2011). The participants moreover specified that incidental reading, sound awareness, letter recognition, reading directionality, syllabification as well as language and auditory development could all be affected by ADHD. Phonological development is based on adequate oral language and, in turn, impacts the development of reading competency (Wium \& Louw 2015). Language and literacy development is consequently also affected by ADHD (De Jongh et al. 2019).

Another response category which emerged from the open-ended questions echoed that a multimodal treatment approach (involving teachers, parents and professionals) should be included in support of learners with comorbid conditions such as emergent literacy difficulties. Research by De Jongh (2017), De Jongh et al. (2019) and Lessing and De Wit (2008) indicate that many teachers do not adequately assist learners when comorbidities of ADHD arise. This might be because of insufficient knowledge as Grade $\mathrm{R}$ teachers were not previously required to have a formal teaching qualification (De Jongh 2017; Lessing \& De Witt 2008; Wium \& Louw 2015).

Responses by the semi-rural participants also reflected a misinterpretation of some of the open-ended questions, and this might be because of lower qualifications in the semi-rural group, as well as limited proficiency in English, as English generally is their second language (Nel \& Müller 2010). Another possibility could be because of a restricted ability to read and write in English (Wium 2010). Although knowledge gains in training are mainly dependent on adequate language skills (Nel \& Müller 2010), the semi-rural participants improved their general knowledge of emergent literacy, probably as a result of the training. This might partially be attributed to the input provided by the assistant researcher who took part in the training and code-switched whenever participants displayed difficulties with the understanding and interpretation of the content provided in the support programme. This was a positive attribute of the support provided.

Urban participants' knowledge on the development, management and support of emergent literacy (including the role of team members) was adequate. Speech-language therapists should support teachers in the management of emergent literacy, as they have the expertise to facilitate language and listening as prerequisites for the development of 
TABLE 5: Overall findings for both groups: Statistically significant differences in knowledge for each of the areas assessed.

\begin{tabular}{lcc}
\hline Aspects assessed & $p$-values & $\begin{array}{c}\text { Statistically significant } \\
\text { difference (Yes/No) } \\
\text { for the two groups }\end{array}$ \\
\hline Understanding of ADHD & 0.194 & No \\
Diagnosis of ADHD & 0.122 & No \\
Referral process & 0.296 & No \\
ADHD symptoms & 0.822 & No \\
Activity levels associated with ADHD & 0.456 & No \\
$\begin{array}{l}\text { Participants' opinions on the behaviour of } \\
\text { learners }\end{array}$ & 0.217 & No \\
$\begin{array}{l}\text { Maturity levels of learners with ADHD } \\
\text { Teacher support for learners with ADHD }\end{array}$ & 1.000 & No \\
$\begin{array}{l}\text { External support provided to learners } \\
\text { with ADHD }\end{array}$ & 0.789 & No \\
$\begin{array}{l}\text { Impact of pharmacotherapy on } \\
\text { ADHD behaviour }\end{array}$ & 0.789 & No \\
Characteristics of emergent literacy & 0.203 & No \\
Teacher support for emergent literacy & 0.655 & No \\
\hline
\end{tabular}

Source: De Jongh, M., 2017, 'The development of a support programme for grade R teachers to facilitate knowledge of attention deficit hyperactivity disorder and emergent literacy in a District of Tshwane', Doctoral dissertation, Sefako Makgatho Health Sciences University, Ga-Rankuwa, Pretoria

$A D H D$, attention deficit hyperactivity disorder.

PA. Teachers with more recent qualifications, such as was the case with the teachers from the urban context who were younger, might have accrued sufficient background knowledge on this matter (Wium \& Louw 2015). From the demographic information obtained, the semi-rural school participants were on average much older than their urban peers, who had received inadequate training under the Apartheid.

The quantitative and qualitative results for all areas show knowledge gains in all trained aspects. The overall outcomes of the training depicting the quantitative results obtained with the Fischer exact test is shown in Table 5.

Once again, these findings propose that the semi-rural school participants' knowledge improved more as a result of the training as there are no statistically significant differences in knowledge for any of the areas assessed after the training for the two groups, because they have all started from a lower base. A summary of the open-ended questions in the last section of the post-training questionnaire provided evidence that the support programme was beneficial and generally met the participants' needs and expectations. The participants indicated personal gains as a result of the training; and expressed their appreciation as $82 \%$ of the participants of the semi-rural context and $95.2 \%$ of the participants in urban schools responded positively. In their opinion, they felt: 'I can contribute more ... and positively ... influence the parents' (De Jongh 2017:330).

The participants also perceived enhanced awareness and understanding of ADHD and emergent literacy, specifically concerning aspects related to the behaviour associated with ADHD. Knowledge gains were seen in the identification and management of ADHD as well as the management of emergent literacy as teachers indicated that they dealt with 'these kind of children', but that they generally did not know how to cope with learners with ADHD and that the training has given them a new perspective (De Jongh et al. 2019).

Participants from urban schools also specified that they no longer regarded ADHD as an illness, and the semi-rural school participants reported that their misconceptions and negative attitudes towards learners with ADHD and their parents changed as a result of the training. The outcomes of the training created a mind-shift in how the participants viewed ADHD. Topkin, Roman and Mwaba (2015) suggest that training of teachers should not be one-off, but should be done continuously. Future training should also address actual problems that might arise in the classroom as reported by the participants.

\section{Integrity of the research}

The self-constructed questionnaires were adapted from an existing tool, the KADDS, which increased the validity thereof. The reliability of these self-constructed questions was increased by pilot testing prior to use. The use of more than one assessment method where quantitative data was supported by the qualitative data across two contexts increased the trustworthiness of the findings.

The validity could have been compromised by the use of a convenience sample and the occurrence of non-response in some of the questions. Another limitation of the research is that only one school district was included, which impacts on the external validity.

\section{Recommendations}

Future support programmes should focus particularly on teachers in semi-rural contexts, emphasising the identification and management of ADHD. Such management should emphasise the importance of a multimodal treatment approach that would include different role players (e.g. speech-language therapists, occupational therapists, psychologists) as well as pharmacotherapy. Future support programmes should also make use of indigenous language speakers to present the training in the home language in various contexts. Where needed in such contexts, the use of interpreters could also be of benefit.

\section{Conclusion}

This article presents the outcomes of a support programme for Grade $\mathrm{R}$ teachers on ADHD in two different contexts. The results obtained from this study confirmed that teachers from a previously disadvantaged context benefitted more from the training than their counterparts in urban contexts because they had less prior knowledge. Teachers from semi-rural, previously disadvantaged contexts have been insufficiently trained and/or less supported to identify and manage learners with ADHD and must recognise the link that exists between ADHD and emergent literacy. Adequate management of ADHD in the preschool years (Grade R) will enhance the 
development of emergent literacy, specifically PA skills that are a prerequisite for reading and writing.

Education policies such as White Paper 6, the RNCS and CAPS amongst others, aim to redress previous inequities by retraining and supporting teachers, specifically those in the Foundation Phase (Motshekga 2011). The retraining of teachers and teacher support is, therefore, fundamental (Motshekga 2013). Teacher support programmes (such as this one on ADHD and associated pre-literacy and literacy-related problems) could bring about change in learners who exhibit barriers to learning (Wium 2010). Speech-language therapists working in educational contexts should make sure that all teachers are knowledgeable about ADHD and able to support learners whilst managing the disorder.

The collaboration between parents, colleagues, psychologists, medical practitioners and therapists is important in managing learners with ADHD, as stated by Mahlo (2011):

$[T]$ he learner does not exist in isolation from surrounding systems, but rather they help determine success in his or her academic career. If all the systems work well together, all learners in schools, even those who experience barriers, should benefit. (p. 21)

Given the relevance of this study, support of teachers with regards to ADHD and its effect on emergent literacy should be further implemented in other districts and more specifically for teachers in previously disadvantaged contexts. Information on ADHD could also be beneficial to other relevant stakeholders such as the DBE, district facilitators, education specialists, therapists and psychologists. This provided a point of reference for the development of support programmes to facilitate teachers' knowledge of ADHD.

\section{Acknowledgements}

\section{Competing interests}

The authors have declared that no competing interests exist.

\section{Authors' contributions}

M.d.J. was responsible for conceptualisation, planning, design, drafting, data collection, analyses and editing. A.M.W. was responsible forconceptualisation, planning, drafting and editing (co-supervisor on the original dissertation).

\section{Funding information}

The researcher (M.d.J.) received a study grant from the Sefako Makgatho Health sciences University for the original research/PhD dissertation.

\section{Data availability}

Data sharing is not applicable for this article as no new data were created or analysed in this study.

\section{Disclaimer}

The views an opinions expressed in this article are those of the authors and do not necessarily reflect the official policy or position of any affiliated agency of the authors.

\section{References}

Adedokun, O.A. \& Burgess, W.D., 2011, 'Analysis of paired dichotomous data: A gentle introduction to the McNemar Test in SPSS', Journal of Multi-Disciplinary Evaluation $8(17), \quad 125-131$, viewed n.d., from http://journals.sfu.ca/jmde/index.php/ jmde_1/index.

Alkahtani, K.D., 2013, 'Teachers' knowledge and misconceptions of attention deficit/ hyperactivity disorder', Psychology 4(12), 963. https://doi.org/10.4236/ psych.2013.412139

American Psychological Association (APA), 2013, Diagnostic and statistical manual of mental disorders $\left(D S M-5^{\circ}\right)$, APA, Washington, DC.

Amod, Z., Vorster, A. \& Lazarus, K., 2013, 'Attention-deficit/hyperactivity disorder (ADHD) as a barrier to learning \& development within the South African context: The perspective of teachers', in S. Banerjee (ed.), Attention deficit hyperactivity disorder in children and adolescents, pp. 215-241, Intech, Rijeka.

Bronfenbrenner, U., 1979, The ecology of human development, Harvard University Press, Cambridge, MA.

Bronfenbrenner, U., 2005, Making human beings human: Bioecological perspectives on human development, Sage, Thousand Oaks, CA.

Chinawa, J.M., Odetunde, O.I., Obu, H.A., Chinawa, A.T., Bakare, M.O. \& Ujunwa, F.A., 2014, 'Attention deficit hyperactivity disorder: A neglected issue in the developing world', Behavioural Neurology 2014, 694764. https://doi.org/10.1155/2014/ 694764

Creswell, J.W., 2014, Research design: Qualitative, quantitative and mixed methods approaches, 4th edn., Sage, Thousand Oakes, CA.

De Jongh, M., 2017, 'The development of a support programme for grade $\mathrm{R}$ teachers to facilitate knowledge of attention deficit hyperactivity disorder and emergent literacy in a District of Tshwane', Doctoral dissertation, Sefako Makgatho Health Sciences University, Ga-Rankuwa, Pretoria.

De Jongh, M., Wium, A.-M. \& Basson, W., 2019, 'The piloting of a specific support programme for Grade R teachers on attention deficit hyperactivity disorder: The process of development', South African Journal of Communication Disorders 66(1), a600. https://doi.org/10.4102/sajcd.v66i1.600

Department of Education (DoE), 2001, Education white paper 6: Special needs education: Building an inclusive education and training system, Department of Education, Pretoria, viewed 21 July 2015, from http://www.polity.org.za/govdocs/ whitepapers/educ6.html.

Flisher, A.J. \& Hawkridge, S., 2013, 'Attention deficit hyperactivity disorder in children and adolescents: The South African Society of Psychiatrists (SASOP) treatment guidelines for psychiatric disorders', South African Journal of Psychiatry 19(3), 136-140. https://doi.org/10.4102/sajpsychiatry.v19i3.943

Guerra, J.F.R. \& Brown, M.S., 2012, 'Teacher knowledge of ADHD among middle school students in South Texas', Research in Middle Level Education Online 36(3), 1-7. https://doi.org/10.1080/19404476.2012.11462096

Gumede, M., 2017, 'Teacher training in spotlight', Sowetan live, July 31, viewed n.d., from https://www.sowetanlive.co.za/news/2017-07-31-teachertraining-in-spotlight/.

Howie, S.J., Combrinck, C., Tshele, M., Roux, K., McLeod Palane, N. \& Mokoena, G., 2018, PIRLS 2016 Progress in International Reading Literacy Study 2016 Grade 5 benchmark participation: South African children's reading literacy achievement, Centre for Evaluation and Assessment (CEA), Pretoria.

Jones, H.A. \& Chronis-Tuscano, A., 2008, 'Efficacy of teacher in-service training for attention-deficit hyperactivity disorder', Psychology in the Schools 45(10), 918-929. https://doi.org/10.1002/pits.20342

Kern, A., Amod, Z., Seabi, J. \& Vorster, A., 2015, 'South African Foundation Phase teachers' perceptions of ADHD at private and public schools', Internationa Journal of Environmental Research and Public Health 12(3), 3042-3059. https:// doi.org/10.3390/ijerph120303042

Lessing, A. \& De Witt, M.W., 2008, 'Do teachers know what the essential literacy skills are?', Paper presented at Laying Solid Foundations for Learning Meeting, Makopane, 30 September-1 October 2008.

Lessing, A.C. \& Wulfsohn, R., 2015, 'The potential of behaviour management strategies to support learners with attention deficit hyperactivity disorder in the classroom', Education as Change 19(1), 54-77. https://doi.org/10.1080/1682320 6.2015.1024146

Lopes, M.A., 2008, 'South African educators' experiences of learners who may have ADHD in their classrooms', Doctoral dissertation, University of Pretoria, Pretoria.

Mahlo, F.D., 2011, 'Experiences of learning support teachers in the foundation phase with reference to the implementation of inclusive education in Gauten', Doctoral dissertation, University of South Africa, Pretoria.

Modisaotsile, B.M., 2012, 'The failing standard of basic education in South Africa', Policy Brief 72, 1-7.

Mohangi, K., Krog, S., Stephens, O. \& Nel, N., 2016, 'Contextual challenges in early literacy teaching and learning in grade $R$ rural schools in South Africa', Per Linguam: A Journal of Language Learning=Per Linguam: Tydskrif vir Taalaanleer 32(1), 71-87. https://doi.org/10.5785/32-1-646 
Motshekga, A., 2011, Statement of the release of the annual national assessment results for 2011, viewed n.d., from https://www.education.gov.za/Newsroom/ results for 2011, viewed n.d., from
Speeches/tabid/298/Default.aspx.

Motshekga, A., 2013, Speech by Mrs Angie Motshekga - Minister of Basic Education 5th Biennial National Conference 2013, ETDA Seta. Gallaghar Estate, Midrand, 25 March.

Murray, E.K., 2009, 'Managing attention deficit hyperactivity disorder in schools: What teachers and parents believe and know', Unpublished DPhil. thesis, Murdoch University.

Nel, N. \& Müller, H., 2010, 'The impact of teachers' limited English proficiency on English second language learners in South African schools', South African Journa of Education 30(4), 635-650. https://doi.org/10.15700/saje.v30n4a393

Olivier, A., Anthonissen, C. \& Southwood, F., 2010, 'Literacy development of English language learners: The outcomes of an intervention programme in Grade $\mathrm{R}^{\prime}$ South African Journal of Communication Disorders 57(1), 58-65. https://doi. org/10.4102/sajcd.v57i1.50

Owens, R.E., Metz, D.E. \& Farinella, K.A., 2010, An introduction to communication disorders: A lifespan evidence based perspective, Pearson Education, London.

Paul, R. \& Norbury, C., 2012, Language disorders from infancy through adolescence: Listening, speaking, reading, writing, and communicating, Elsevier Health Sciences, Edinburgh.

Perold, M., Louw, C. \& Kleynhans, S., 2010, 'Primary school teacher's knowledge and misperceptions of Attention Deficit Hyperactivity Disorder (ADHD)', South African Journal of Education 30(3), 457-473. https://doi.org/10.15700/saje. v30n3a364

Procaccini, J.C., 2013, 'Development and assessment of an accelerated AD/HD training for teachers in elementary schools', Doctoral dissertation, Union Institute and University.

Schellack, N. \& Meyer, H., 2012, 'The management of attention deficit-hyperactivity disorder in children: Evidence-based pharmacy practice', SA Pharmaceutical Journal 79(10), 12-20, viewed 15 November 2016, from https://www.sapj.co.za.

Sciutto, M.J., Terjesen, M.D. \& Frank, A.S.B., 2000, 'Teachers' knowledge and misperceptions of attention-deficit/hyperactivity disorder', Psychology in the Schools 37(2), 115-122. https://doi.org/10.1002/(SICI)1520-6807(200003)37:2\% 3C115::AID-PITS3\%3E3.0.CO;2-5
Sims, D.M. \& Lonigan, C.J., 2013, 'Inattention, hyperactivity, and emergent literacy: Different facets of inattention relate uniquely to pre-schoolers' reading related skills', Journal of Clinical Child and Adolescent Psychology 42(2), 208-219. https:// skills', Journal of Clinical Child and Adolescen
doi.org/10.1080/15374416.2012.738453

Spangler, J.M. \& Slate, J.R., 2012, 'Elementary school teacher perceptions of attention deficit hyperactivity disorder', Mercer Journal of Educational Leadership 1(1), 1-28, viewed from https://librairies:mercer.edu/ursa/handle.

Spaull, N., 2013, South Africa's education crisis: The quality of education in South Africa 1994-2011, Johannesburg Centre for Development and Enterprise, Johannesburg, pp. 1-65, viewed 15 November 2016, from https:// www.cde.org.za.

Suvarna, B.S. \& Kamath, A., 2009, 'Prevalence of attention deficit disorder among preschool age children', Nepal Medical College Journal 11(1), 1-4, viewed 20 July 2015, from https://www.nepjol.info.

Syed, E.U. \& Hussein, S.A., 2010, 'Increase in teachers' knowledge about ADHD after a week-long training program: A pilot study', Journal of Attention Disorders 13(4), 420-423. https://doi.org/10.1177/1087054708329972

Thomas, E.J. \& Rothman, J., 1994, 'An integrative perspective on intervention research', in J. Rothman \& E.J. Thomas (eds.), Intervention research, pp. 3-24, Haworth Press, New York.

Topkin, B., Roman, N.V. \& Mwaba, K., 2015, 'Attention deficit disorder (ADHD): Primary school teachers' knowledge of symptoms, treatment and managing classroom behaviour', South African Journal of Education 35(2), 1-8. https://doi. org/10.15700/saje.v35n2a988

Wessels, E., 2011, 'Teacher knowledge and implementation of phonological awareness in Grade R', Doctoral dissertation, North-West University, Potchefstroom.

Wium, A.M., 2010, 'The development of a support programme for foundation phase teachers to facilitate listening and language for numeracy', Doctoral dissertation, University of Pretoria, Pretoria.

Wium, A.M. \& Louw, B., 2013, 'Revisiting the roles and responsibilities of speech-language therapists in South African schools', South African Journal of Communication Disorders 60(1), 31-37. https://doi.org/10.4102/sajcd.v60i1.8

Wium, A.M. \& Louw, B., 2015, 'CAPS: Implications for collaboration between teachers and speech-language therapists working in schools', South African Journal of Childhood Education 5(1), 19-41. https://doi.org/10.4102/sajce.v5i1.348 